\title{
MINERALOGY OF OXIDES FROM KIMBERLITE GROUNDMASS: GENETIC AND APPLIED ASPECTS (AN EXAMPLE FROM THE YAKUTIAN DIAMOND PROVINCE)
}

\author{
ANGELIKA VALERIANOVNA BOVKUN ${ }^{1}$, VICTOR KONSTANTINOVICH GARANIN ${ }^{1} \&$ GALINA PRTROVNA \\ KUDRYAVTSEVA ${ }^{1}$
}

\begin{abstract}
Microcrystalline oxides (spinel, ilmenite, and perovskite) in the groundmass of kimberlite and related rocks were analyzed from mine kimberlite fields of the Yakutian Diamond Province. Modal abundances and chemical compositions of the oxide phases are useful parameters for kimberlite prospecting and to evaluate kimberlite generation and evolution. There are four different oxide parageneses in the groundmass of the studied rocks, which correspond to high-Mg kimberlites with chromium spinel, magnesian-ferrous kimberlites with chromespinel-picroilmenite, magnesian-ferrous-titanium kimberlites with picroilmenite-titanomagnetite and related rocks (picrites and alnoites) with titanomagnetite-perovskite. The differences in microcrystalline oxides are a sensitive indicator of kimberlite diamond grade.
\end{abstract}

Keywords: kimberlite, diamond, groundmass, oxides, diamond potential, prospecting

INTRODUCTION Mineralogical criteria are recognized as very useful for diamond potential evaluation in kimberlites. For example, the widely known $\mathrm{CaO}-\mathrm{Cr}_{2} \mathrm{O}_{3}$ diagrams for garnets, the $\mathrm{TiO}_{2}-\mathrm{Cr}_{2} \mathrm{O}_{3}$ and $\mathrm{Al}_{2} \mathrm{O}_{3}-\mathrm{Cr}_{2} \mathrm{O}_{3}$ diagrams for chromespinels with respective discriminant fields for pyrope and chromite inclusions in diamond from rocks with dunite-harzburgite paragenesis (Sobolev 1974, Gurney, 1984). The modern classifications were designed on the basis of a garnet composition database from different types of mantle rocks and kimberlites (Dawson \& Stephens 1975) with discrimination of a highchromium low calcium group of garnets (known as G 10) from diamond bearing associations and also (Garanin et al., 1991) on the basis of chemical-genetic classifications of garnet, olivine, clinopyroxene, chromespinel and ilmenite inclusions in diamond, diamond bearing rocks and other basic and ultrabasic rocks, with individualized groups of such minerals in association with diamond.

It is now known that among diamond bearing kimberlites there are also rocks which contain very low amounts of heavy minerals (for example, the kimberlites of the Arkhangelsk province (Bogatikov et al. 1999). On the other hand, investigation of kimberlites for diamond potential produces both minerals derived from mantle rocks and minerals derived from the kimberlite groundmass, but the latter have not received a great deal of attention so far.

The diamond deposit problems laboratory of the Geological Faculty at Moscow State University have paid much attention to the analysis of groundmass oxide minerals from kimberlite bodies with variable diamond grade over many years. Special emphasis was given to determination of oxide minerals ratio, their composition, and correlation of these data with the diamond potential of investigated bodies.

As a result, it was established, that oxides from the kimberlite groundmass (Bovkun 2000, Bogatikov et al. 1999, Garanin et al. 1986, 1987, 1991) can carry very relevant information on the depth of kimberlite magma generation, including diamond bearing kimberlites, and about preservation of diamonds, since the dynamics of kimberlite melt rise influences the evolution of diamond as well as of other minerals from kimberlites.

RESULTS The oxide studies and their application for evaluation of kimberlite diamond potential Spinels, ilmenite and perovskite, their mutual relations, and their relations with other rock-forming groundmass minerals, play a key role as sensitive criteria of diamond potential in kimberlite bodies of Yakutian Diamond Province (YDP).

We studied minerals from the groundmass of 30 kimberlite pipes with different diamond grade in nine kimberlite fields from the centeral and northern portions of the YDP. Within the limits of the province, four basic types of kimberlite rocks were recognized, on the basis of oxide mineralization:

HIGH-MAGNESIAN KIMBERLITES WITH GROUNDMASS CHROMESPINEL This group corresponds extremely highgrade diamond bearing kimberlite pipes (Botuobinskaya, Nyurbinskaya, Aikhal, Internatsionalnaya), one medium-grade pipe (Yubileinaya), several low-grade pipes of the Kharamaiskoye field and one non-diamond bearing pipe Obnazhennaya. In these pipes, the most common heavy minerals are pyrope and chromespinel, while picroilmenite is practically absent. The groundmass oxide minerals content is low $(<3$ vol.\%). The most abundant oxide phase corresponds to chromespinel, which can reach up to 95 vol.\% in high grade diamond bearing kimberlite pipes. Manganic and ferrous ilmenite ranges from 10 to $60 \mathrm{vol} . \%$, and perovskite from 0 to $70 \mathrm{vol} . \%$. High contents of ilmenite and perovskite are typical of both low-diamond and non-diamond bearing kimberlites.

A uniform trend evolves from picrochromite (>56-59 wt.\% $\mathrm{Cr}_{2} \mathrm{O}_{3}$ and 2 wt. $\% \mathrm{TiO}_{2}$ ) for extremely rich pipes; to Tibearing picroferroferrichromites (41 wt. $\% \mathrm{Cr}_{2} \mathrm{O}_{3}$ and $7-8 \mathrm{wt} . \%$ 
$\mathrm{TiO}_{2}$ ) for the non-diamond bearing Obnazhennaya kimberlite.

MAGNESIAN-FERROUS KIMBERLITES WITH GROUNDMASS CHROMESPINEL-PICROILMENITE Pipes of this type are widespread in the YDP. It comprises high-grade pipes (Mir, Udachnaya), medium-grade pipes (Sytykanskaya, Zarnitsa), low-grade pipes (Djanga, Universitetskaya) and others. The high picroilmenite, pyrope and pyrope-almandine contents are characteristic, as well as the cleary subordinate character of the at the chromespinels. Oxide minerals comprise $5-20 \mathrm{vol} . \%$. of the kimberlite groundmass. Spinels (35-55 vol.\%) and ilmenite (35-50 vol.\%) dominate, and perovskite $(10-15 \mathrm{vol} . \%)$ is subordinate in the diamond bearing bodies. In low-grade bodies, the perovskite content increases (from 20 up to $80 \mathrm{vol} . \%)$, and ilmenite content noticeably decreases (5-30 vol.\%).

Two similar evolutionary trends are recognized for spinel and ilmenite, respectively. The spinel trend begins with medium-crhomium picroferrochromites (49-52 $\mathrm{wt} . \mathrm{C}_{2} \mathrm{C}_{3}$ and 2.5-5.5 wt. \% $\mathrm{TiO}_{2}$ ) for diamond bearing pipes, progresses with medium-crhomium picroferrichromites (42-44 wt. $\% \mathrm{Cr}_{2} \mathrm{O}_{3}$ and $5-7 \mathrm{wt}_{\mathrm{O}} \% \mathrm{TiO}_{2}$ ) for low-diamond bearing pipes, and with magnesian $\mathrm{Cr}$-bearing ulvospinel $\left(37-38 \mathrm{wL} \% \mathrm{Cr}_{2}{ }_{2}\right.$ and $9-10$ wt. $\% \mathrm{TiO}_{2}$ ) for non-diamond bearing pipes, being completed in all cases by the crystallization of titanomagnetite. The ilmenite trend begins with picroilmenite for diamond bearing pipes. For non-diamond bearing bodies the Mn-bearing ilmenite is characteristic only.
MAGNESIAN-FERROUS-TITANIUM KIMBERLITES WITH GROUNDMASS PICROILMENITE-TITANOMAGNETITE SPECIALIZATION OF OXIDES These rocks correspond to low-diamond bearing and non-diamond bearing pipes (Leningradskaya, Morkoka). Among the heavy minerals picroilmenite is abundant, pyrope is subordinate, and chromespinels are extremely rare. The oxide contents are $4-5$ vol.\%. Chromespinels are not found in the kimberlite groundmass, while titanomagnetite and magnetite are widespread (up to $40 \%$ ), picroilmenite and $\mathrm{Mn}$-ilmenite are abundant (40-90\%) and perovskite varies from 5 up to $20 \%$. Only one picroilmeniteilmenite trend with preferential distribution of $\mathrm{Mn}$-ilmenite is established.

\section{KIMBERLITE-RELATED ROCKS (PICRITES AND} ALNOITES) WITH GROUNDMASS TITANOMAGNETITEPEROVSKITE This group comprises non-diamond bearing rocks such as the carbonatites of the Velikan dyke and the montichellite alnoites of the Montichellitovy stock.

The low abundance of heavy minerals (pyrope, chromespinel and picroilmenite), and the high contents of groundmass oxide minerals (10-20 vol.\%, equally distributed between titanomagnetite and perovskite) are characteristic. The composition trend evolves from $\mathrm{Cr}$-bearing ulvospinels (21-24 wt. $\% \mathrm{Cr}_{2} \mathrm{O}_{3}$ and $10-13$ wt. $\% \mathrm{TiO}_{2}$ ) to magnetite.

Composition data for chromespinel from the kimberlite groundmass are presented in Table 1. Trends of chromespinel

Table I - Composition features of groundmass chromespinels (wt.\%) from YDP kimberlites (these spinels correspond to the earliest stages of spinel crystallization in kimberlite pipes)

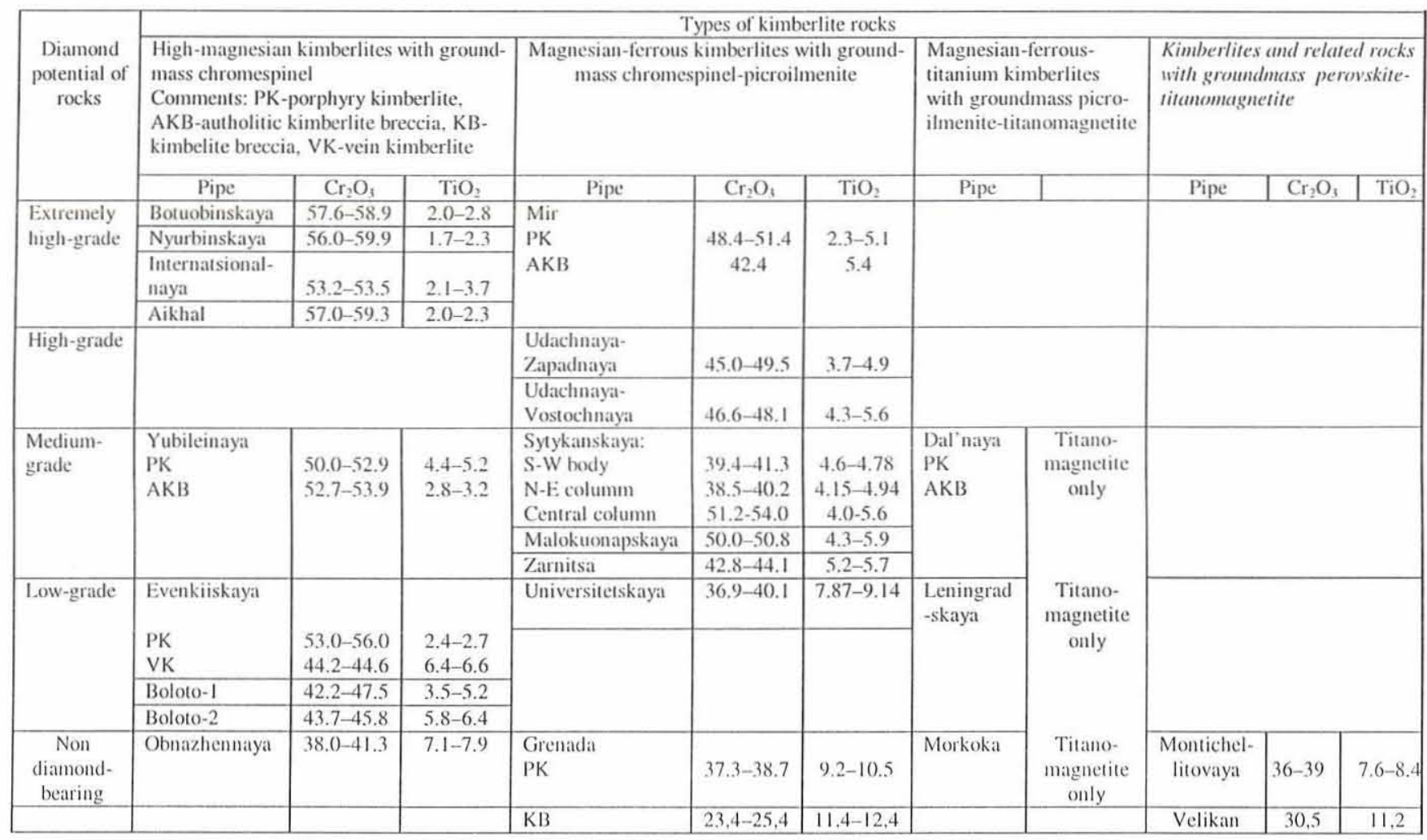




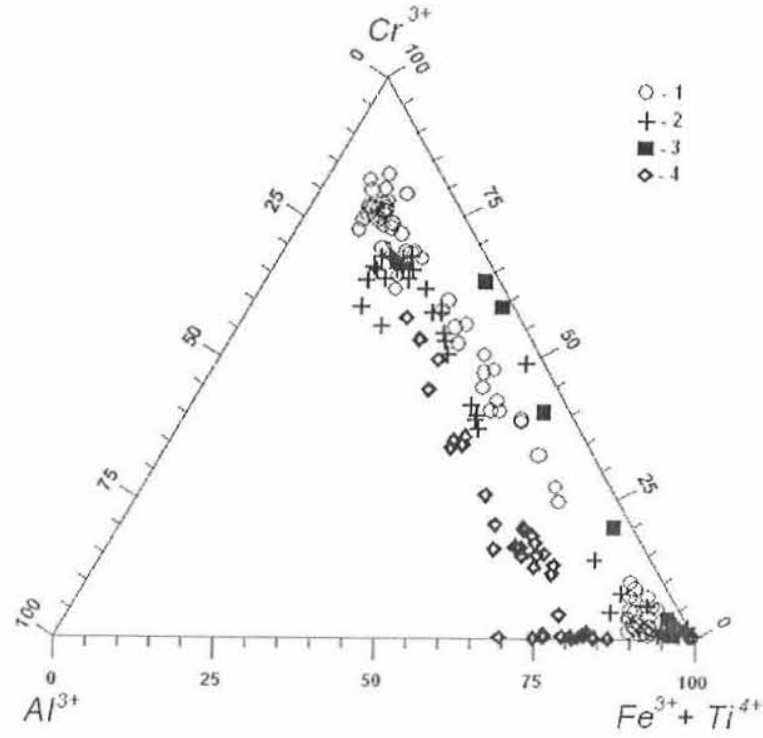

Figure I - Compositions of groundmass chromespinel of the Aikhal (I), Udachnaya (2), Obnazhennaya (3) kimberlite pipes and the Montichellitovaya alnoitic stock, Yakutian Diamond Province.

compositions from the groundmass of kimberlite with different diamond grade are illustrated on Fig. I, 2.

Representative analysis of groundmass chromespinel and ilmenite (more than 1000 analyses for each mineral) from all studied kimberlite bodies and picrites were compounded in a database. Cluster analysis was carried out in order to establish the grouping of these minerals. A chemical-genetic classification is proposed, on the basis of composition ranges of the studied minerals (groups), comprising high-, medium-, and low-grade diamond bearing kimberlites, non-diamond bearing kimberlites and picrites. Based on oxide content and correlations, 15 groups were recognized for spinel and 11 for ilmenite. The proportion of these groups among pipes with different diamond potential varies. A new method for the evaluation of kimberlite diamond potential is proposed, based on the calculation of discriminant funcions for all groups compositional features of groundmass spinels and ilmenite, and perovskite abundance.

The criteria for distinguishing diamond bearing kimberlites

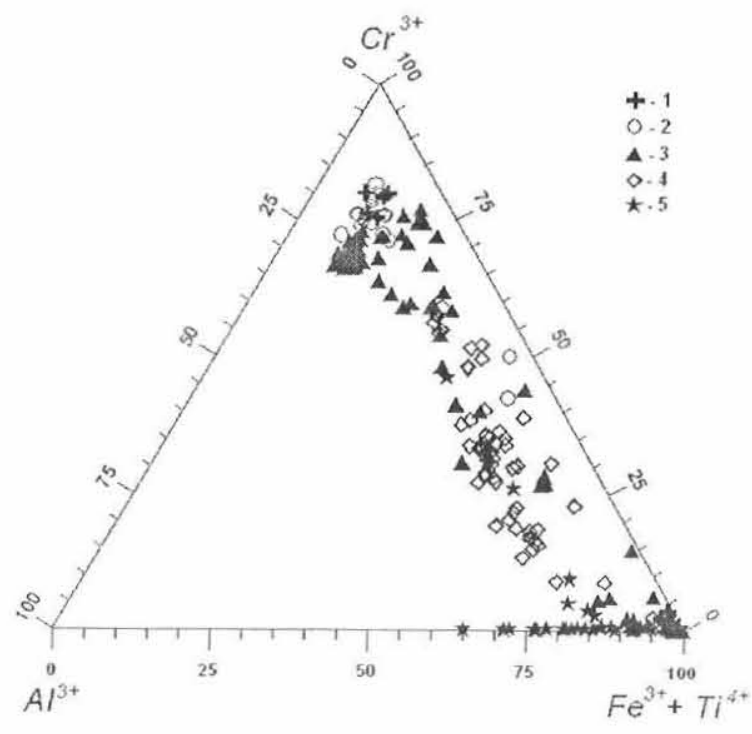

Figure 2 - Compositions of groundmass chromespinel of the Botuobinskaya (1), Nyurbinskaya (2), Yubileinaya (3), Grenada (4) kimberlite pipes and the Velikan carbonatite dyke (5), Yakutian Diamond Province.

on the first stages of explorations are: presence of chromespinel, containing more than $40 \mathrm{wt}$. $\% \mathrm{Cr}_{2} \mathrm{O}_{3}$ (for extremely rich kimberlites, more than 53 wt. $\% \mathrm{Cr}_{2} \mathrm{O}_{3}$ ) and less than 4 wt. $\% \mathrm{TiO}_{2}$; presence of high-chromium picroilmenite (more than 12 wi. $\% \mathrm{MgO}$ and 2 wt. $\% \mathrm{Cr}_{2} \mathrm{O}_{3}$ ) and absence or low content of perovskite (less than 5 vol. $\%$ ).

The mineralogical criteria defined here on the basis of groundmass oxide mineralization, together with earlier designed chemical-genetic classifications of diamond mineral indicators (Garanin et al. 1991) are the basis of a multifunction automated control system of diamond-bearing kimberlite prospecting, their diamond potential and preliminary evaluation. These criteria and evolution trends were confirmed by results of groundmass oxide mineralization study for kimberlite pipes of Arkhangelsk diamond bearing province (Krotkov et al. 2001).

Acknowledgements To two anonymous referees of RBG for suggestions to the manuscript.

\section{References}

Bovkun A. 2000. Mineralogy of oxides from the groundmass kimberlites of Yakutia (genetic and applied aspects). Dissertation of Master, Geological Faculty, Moscow State University, Moscow, 324 pp.

Bogaticov O.A., Garanin V.K., Kononova V.A., Kudriavtseva G.P. el al. 1999. Arkhangelsk Diamond bearing Province (Geology, Petrography, Geochemistry and Mineralogy). Publishing House of Moscow University, Moscow, 524 pp.

Dawson J.B. \& Stephens W.E. 1975. Statistical analysis of garnets from kimberlites and associated xenoliths. Journal of Geology, 83:589-607.
Garanin V.K., Kudriavtseva G.P., Mikhailichenko O.A. 1986. Mineralogy of ilmenite from the groundmass of kimberlites. In.: Mineralogy of kimberlites and related rocks. Moscow, VINITI, 6967-V86:180-207.

Garanin V.K., Kudriavtseva G.P., Mikhailichenko O.A. 1987.Mineralogy of spinels from the groundmass of kimberlites. In.: Mineralogy and petrology of kimberlites. Moscow, VINITI, 7087-B87:37-130.

Garanin V.K., Kudriavtseva G.P., Marfunin A.S., Mikhailichenko O.A. 1991. Inclusions in diamond and diamond bearing rocks. Publishing House of Moscow University, Moscow, 240 pp. 
Gurney J.J. 1984. A correlation between garnets and diamonds in kimberlites. In J.E. Glover \& P.G. Harris (eds.) Kimberlite Occurrence and Origin: A basis for conceptual models in exploration, Geology Department and University Extension, University of Western Australia, Publication No 8, pp.: 143-166.

Krotkov V.V., Kudriavtseva G.P., Bogatikov O.A., Valuev Yu.P. et al. 2001. New technologies of diamond deposit exploration. Publishing House "GEOS", Moscow, $310 \mathrm{pp}$.
Sobolev N.V. 1974. Deep rocks in kimberlites and problem of composition of the upper mantle. Publishing House Nauka, Novosibirsk, 264 pp.

Manuscrito A-1298

Recebido em 21 de novembro de 2001 Revisão dos autores em 11 de dezembro de 2001 Revisão accita em 12 de dezembro de 2001 